\title{
Case report of a posterior vaginal wall Mullerian cyst
}

\author{
Spyridoula P. Kasioni*, Panagiotis N. Thesalonikefs, Ioannis V. Gialelis
}

Department of Obstetrics and Gynecology, Elena Venizelou Hospital, Athens, Greece

Received: 11 February 2019

Accepted: 07 March 2019

\section{*Correspondence:}

Dr. Spyridoula P. Kasioni,

E-mail: drkasioni@gmail.com

Copyright: (c) the author(s), publisher and licensee Medip Academy. This is an open-access article distributed under the terms of the Creative Commons Attribution Non-Commercial License, which permits unrestricted non-commercial use, distribution, and reproduction in any medium, provided the original work is properly cited.

\begin{abstract}
Mullerian cysts are common types of vaginal cysts, which are small and mainly asymptomatic. Sometimes they present as large symptomatic cystic lesions arising issues of differential diagnosis. They are congenital cysts found anywhere along the length of development of Mullerian duct, occurring typically during the conventional gynaecological examination. Authors report of a premenopausal woman presenting with a small asymptomatic, palpable cystic lesion in the posterior vaginal wall, found during the gynaecological re-examination one month after an open surgery for an ovarian endometrioma excision. The whole lesion was $0.4 \mathrm{~cm}$ and surgically excised under general anesthesia. Postoperative period was completely uncomplicated. Pathology affirmed a benign Mullerian cyst. Although the majority of vaginal cysts may be asymptomatic, a complete excision is required especially in cases of suspected malignancy or other pathology. Clinical examination and imaging are not enough for determining the pathology and a histopathology confirmation is always necessary.
\end{abstract}

Keywords: Cystic lesions, Mullerian cyst, Mullerian duct, Vaginal cyst

\section{INTRODUCTION}

Vaginal cysts are quite uncommon and usually asymptomatic. ${ }^{1}$ Typically they occur in patients' third or fourth decade of life. Differential diagnosis consists of Mullerian cysts, epidermal inclusion cysts, Bartholin duct cyst, Gartner duct cyst, urethrocele, endometriotic cyst, myxomatous tumor and unclassified (Table 1). ${ }^{2} 30-40 \%$ of vaginal cysts are Mullerian, which are remnants of the embryologic paramesonephric pair of ducts and can be found in any point throughout the length of the development of the paramesonephric ducts, meaning that they can be found in the anterior, posterior or lateral vaginal wall ${ }^{3}$. In most cases, these cysts are less than $2 \mathrm{~cm}$ in diameter and are usually asymptomatic. Rarely, their diameter can reach $4 \mathrm{~cm}$ or more and cause discomfort, vaginal pressure, bleeding or dyspareunia. ${ }^{3}$ Mainly, they are lined by endocervical and occasionally by fallopian tubal epithelium. Knowledge of evaluation and treatment of these cysts when encountered in gynecological practice is important. This is a small Mullerian cyst of the posterior vaginal wall.

Table 1: Differential diagnosis of vaginal cysts.

\begin{tabular}{|l|}
\hline Differential diagnosis of vaginal cysts \\
\hline Mullerian cyst \\
\hline Inclusion cyst \\
\hline Mesonephric cyst \\
\hline Bartholin's gland cyst \\
\hline Endometriotic cyst \\
\hline Cystocele \\
\hline Rectocele \\
\hline Enterocele \\
\hline Hematocolpos \\
\hline Myxomatous tumor \\
\hline
\end{tabular}




\section{CASE REPORT}

A 39 year-old woman, para 1, eight days after her menstrual period, visited our outpatient department of obstetrics and gynecology for her routine postoperative gynecological examination. She had a surgical excision of her left adnexa and an $8 \mathrm{~cm}$ endometrioma in our department 30 days ago because of pain in the lower abdomen.

Her surgery and postoperative period was uneventful and her medical history was remarkable only for including systemic lupus erythematosus (SLE) in remission during the last 5 years.

During speculum examination cervix was fine and there was no abnormal vaginal discharge or discomfort. A bluish, lentil sized mass was detected in the lower third of the posterior vaginal wall. On palpation, the mass was cystic, tense, nontender, just right under the vaginal mucosa.

She reported no history of vaginal trauma, dyspareunia or bowel disturbances. No cough impulse was noticed. The patient was advised to have the cyst excised but she chose to come back for examination after 20 days.

In the next examination the cyst was exactly the same, asymptomatic, and the patient was planned to have a cystectomy under general anaesthesia the next day. After sharp dissection, complete excision of the small mass was performed.

Pathology confirmed the diagnosis of a benign Mullerian cyst $0.4 \mathrm{~cm}$ with hemorrhagic material, lined by a single layer of cuboidal, fallopian type epithelium with phagocytic inflammation.

No postoperative complications were noted, and patient was discharged the same day. She was followed up for two months and remained asymptomatic.

\section{DISCUSSION}

Formation of each Mullerian duct begins in the sixth gestational week and will finally form the oviducts, uterus and part of the vagina. ${ }^{4}$

Mullerian vaginal cysts, are remnants of the embryologic paramesonephric ducts that persist in the vagina. Mullerian epithelial tissue can remain anywhere along the vaginal wall, but usually it is located in the anterolateral wall. ${ }^{5}$

Nevertheless, our cyst was found in the lower third of the posterior vaginal wall. Differential diagnosis includes Bartholin cyst which is usually found at the posterior region of the vaginal opening, Gartner duct cyst which is located in the anterior or antero-lateral aspect of vaginal mucosa, inclusion cyst caused by an injury or a surgery in the vaginal wall and endometriotic cyst.

The patient had no vaginal delivery nor vaginal operation or pain noted but due to her history of a large ovarian endometrioma, an endometriotic vaginal cyst should be ruled out by histopathology.

Although usually Mullerian cysts are small and asymptomatic, as in present case, Lallar $\mathrm{M}$ and colleagues aspirated a Mullerian vaginal cyst $8 \times 8 \mathrm{~cm}$ which was protruding during birth, having finally an uneventful vaginal delivery. ${ }^{6}$

Rarely, multiple vaginal cysts exist. ${ }^{7-8}$ Occasionally, they can mimic a cystocele or an enterocele and scarcely they are confirmed to be malignant. ${ }^{3,9,10}$ History, clinical examination, magnetic resonance imaging and ultrasound can be very helpful in preoperative evaluation of the location and size of the mass. ${ }^{11}$

Essentially, MRI detects accompanying anomalies of the genitourinary system. In our patient, per vaginal and per rectal examination was sufficient enough to demarcate the cyst and arrange the operative plan.

Patients with vaginal cysts must be thoroughly informed about the condition and excised cysts ought to be confirmed by histopathology.

\section{Funding: No funding sources Conflict of interest: None declared Ethical approval: Not required}

\section{REFERENCES}

1. Anitha GL, Prathiba MS, Gowri M. An unusual case of anterior vaginal wall cyst. JSAFOG. 2015;7(3):227-30.

2. Fletcher SG, Lemack GE. Benign masses of the female periurethral tissues and anterior vaginal wall. Current Urology Reports. 2008;9(5):389-96.

3. Töz E, Sancı M, Cumurcu S, Özcan A. Müllerian cyst of the vagina masquerading as a cystocele. Case Reports in Obstetrics and Gynecology. 2015;2015.

4. Catherine M. De Ugarte. Embryology of the urogenital system and congenital anomalies of the genital tract. In: Alan H. Decherney, Lauren Nathan, Neri Laufer, Ashley S. Roman, eds. Current Diagnosis and treatment. $11^{\text {th }}$ ed. International Edition, New York: McGraw-Hill; 2013:49-50.

5. Pradhan S, Tobon H. Vaginal cysts: a clinicopathological study of 41 cases. Int J Gynecol Pathol. 1986;5(1):35-46.

6. Lallar M, Nandal R, Sharma D, Shastri S. Large posterior vaginal cyst in pregnancy. BMJ Case Reports. 2015;2015:bcr2014208874.

7. Wai CY, Corton MM, Miller M, Sailors J, Schaffer JI. Multiple vaginal wall cysts: diagnosis and 
surgical management. Obstet Gynecol. 2004;103(5):1099-102.

8. Hwang JH, Oh MJ, Lee NW, Hur JY, Lee KW, Lee JK. Multiple vaginal mullerian cysts: a case report and review of literature. Arch Gynecol Obstet. 2009;280(1):137-9.

9. Davidson ER, Barber MD. A Gartner duct cyst masquerading as anterior vaginal prolapse. Obstet Gynecol. 2017;130(5):1039-41.

10. Lee KS, Park KH, Lee S, Kim JY, Seo SS. Adenocarcinoma arising in a vaginal Müllerian cyst: a case report. Gynecol Oncol. 2005;99(3):767-9.
11. Eilber KS, Raz S. Benign cystic lesions of the vagina: a literature review. J Urol. 2003;170(3):71722.

Cite this article as: Kasioni SP, Thesalonikefs PN, Gialelis IV. Case report of a posterior vaginal wall Mullerian cyst. Int J Reprod Contracept Obstet Gynecol 2019;8:1672-4. 